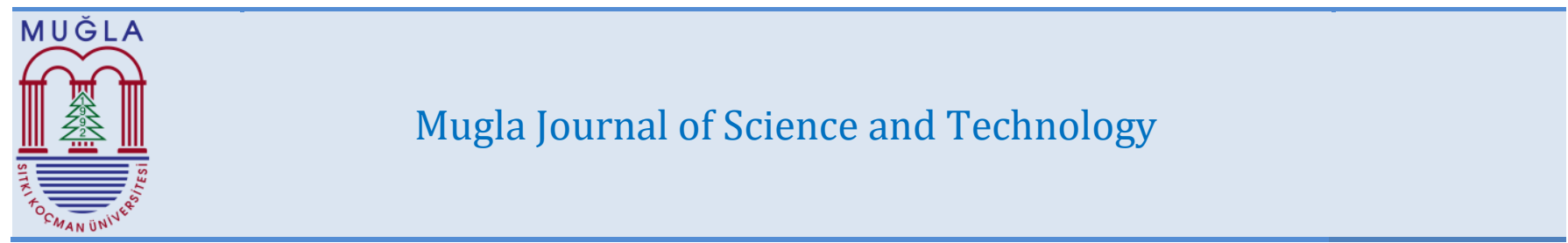

\title{
THE ANTIFUNGAL EFFECTS OF DATURA STRAMONIUM L., D. METEL L., D. INNOXIA Mill. IN FLORA OF TURKEY
}

\author{
Ummahan ÖZ ARIK 1*®D \\ ${ }^{1}$ Manisa Celal Bayar University, Alașehir Vocational School, Medical and Aromatic Plants Program, Manisa, Turkey \\ ummahanoz48@gmail.com
}

Received: 19.09.2017, Accepted: 02.11.2017

*Corresponding author

doi: $10.22531 /$ muglajsci.345175

\begin{abstract}
Medical plants are an important part of our lives. Various plant species have been used medically since ancient times. Most of the modern drugs are derived from plants. The demand for medical and aromatic plants in the world market is increasing. The main commercial centers of herbal drugs in the world are Japan, China, USA, Germany, Hong Kong, England, Italy, France and Spain. Turkey is also in an important position in the medicinal and aromatic plant market. Many plants collected from the nature are used to food, treatment, spices, beverage, and cosmetics etc. fields. In addition to these, researchers are conducting research showing that these crops can also be used in agricultural control. They have been supported by studies that these plants are highly effective against fungi causing harmful effects in plants. For this purpose, antifungal effects of Datura species (Datura stramonium L, D. metel L. ve D. innoxia Mill.) have been reviewed. Researches indicated that Datura sp. have antifungal activity some fungi. However, this effect varies according to concentration and types of solvents, part of plants such as root, seed, leaf, stem etc. The studies carried out show that each of the three Datura species has the potential to be a good fungicide by means of the compounds it contains
\end{abstract}

Keywords: Agricultural control, antifungal, Datura stramonium L., D. innoxia Mill., D. metel L.

\section{TÜRKIYE FLORASINDAKİ DATURA STRAMONIUM L., D. METEL L., D. INNOXIA Mill. TÜRLERININ ANTIFUNGAL ETKİİ}

Öz

Tıbbi bitkiler hayatımızın önemli bir parçasıdır. Eski çağlardan beri çeșitli bitki türleri tıbbi olarak kullanılmaktadır. Modern ilaçların çoğu bitkilerden elde edilir. Dünya pazarında tıbbi ve aromatik bitkilere talep artmaktadır. Bitkisel ilaçların dünyadaki başlica ticaret merkezleri Japonya, Çin, ABD, Almanya, Hong Kong, İngiltere, İtalya, Fransa ve İspanya'dır. Türkiye, tıbbi ve aromatik bitki pazarında da önemli bir konumdadır. Doğadan toplanan birçok bitki gıda, tedavi, baharat, içecek, kozmetik vb. alanlarda kullanılmaktadır. Bunlara ek olarak, araștırmacllar bu ürünlerin tarımsal mücadelede de kullanılabileceğini gösteren araştırmalar yürütmektedirler. Bu bitkilerin, bitkilerde zararlı etkilere neden olan mantarlara karşı oldukça etkili oldukları çalșmalarıly desteklenmektedir. Bu amaçla, Datura türlerinin (Datura stramonium L, D. metel L. ve D. innoxia Mill.) antifungal etkileri derlenmiștir. Araştırmalar, Datura türlerinin bazı mantarlara karşı antifungal aktivite gösterdiğini bildirmektedir. Bununla birlikte, bu etki, konsantrasyon ve solvent tiplerine, kök, tohum, yaprak, gövde gibi bitkilerin bölümlerine göre değişmektedir. Yapılan çalışmalar, üç Datura türünün her birinin, içerdikleri bileşikler vasitasiyla iyi bir fungisid olma potansiyeline sahip olduğunu göstermektedir.

Anahtar Kelimeler: Tarımsal mücadele, antifungal, Datura stramonium L., D. innoxia Mill., D. metel L.

\section{Introduction}

Medical plants are an important part of human life. In recent years, the alternative medicine system is in an important position. The value of herbal medicines is increasing because of the decrease in the level of the effect of synthetic drugs. The plants collected from nature are also used in food, treatment, spices, soft drinks, cosmetics and agricultural control. Fungal disease are observed very much nowadays and as a result yield losses occur. As the used fungicide-resistant strains grow, new drug searches are emerging. The use of medicinal plants for treating fungal infections is an advantage. The use of plants as antifungal agents may be an alternative to minimizing the residual problem.

Datura is a member of the family Solanaceae and is represented in our country by three species, Datura stramonium L., D.innoxia Mill., D. metel L.

Datura L. genus leaves are sinuate- dentate to entire. Flowers are solitary, axillary. This genus has tubular, 5-angled calyx and infundibular corolla. Stamens inserted near base of corolla. Fruit is a septicidal capsule [1] .

D. stramonium L. is a perennial herbaceous plant. Leaves are simple, alternate, dark green, broadly ovate, shallowly lobed and glabrous. Flowers are large, solitary and trumpet-shaped [2]. In some literature, this species is called thorn apple and jimson weed [3].

D.metel L. is a perennial green shrub, shrub or perennial herbaceous plant. Leaves are simple, alternate, long and green. Their margin is sinuate-dentate and the fruit is a very seedy capsule [4].

D.innoxia Mill. is a densely pubescent plant. Leaves are petiolate, ovate, largely sinuate to entire [1]. 


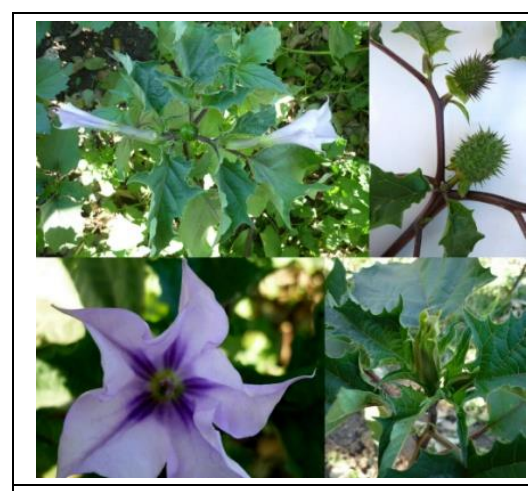

(a)

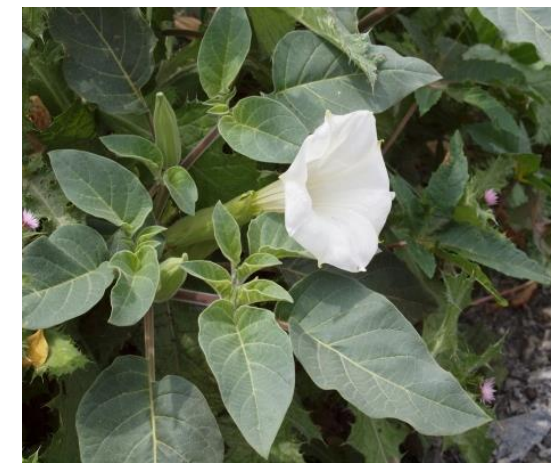

(b)

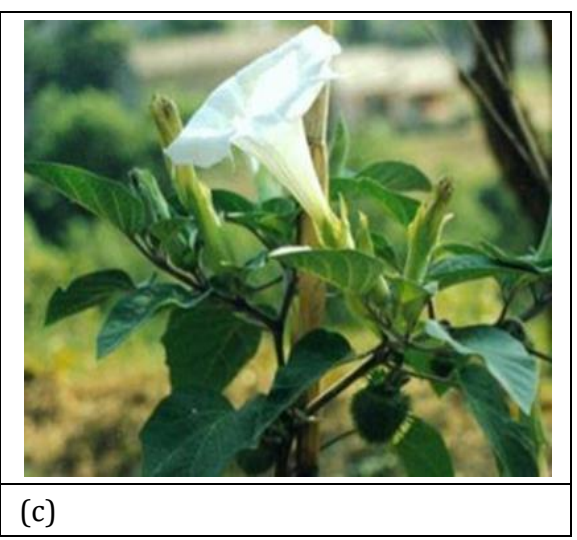

(c)

Figure 1: a)D. stramonium L., b) D.innoxia Mill., c) D. metel L. [5].

Secondary metabolites in plants have strong antibacterial and antifungal properties. It has been reported that the antimicrobial properties of Datura plant originate from compounds such as alkaloids, triterpenoids, steroids, flavonoids, triterpenes, phenolic compounds and tannins [6].

Datura sp. produce the alkaloids such as hyoscyamine and scopolamine used in pharmacology [7]. Philipov and Berkov [8] found 29 tropane alkaloids in the root, leaf and seed of Datura stramonium L. by GC-MS method in their study.

Datura stramonium L. has antibacterial, nematicidal, antifungal, contact toxicity, anticancer, antioxidant, antimicrobial, acaricidal, repellent and oviposition deterrent effects [3].

Datura stramonium L. leaves contain alkaloids in the range of $0.2-0.6 \%$. Atropine, one of the active tropane group alkaloids, is commonly used in eye diseases and paralysis resulting from the nervous system [9]. Atropine is also used in Parkinson's disease, diarrhea, bronchial asthma and peptic ulcer [10]. Atropine intake in excess of $10 \mathrm{mg}$ may potentially have a lethal effect. Each of the DS seeds contains about $0.06 \mathrm{mg}$ of atropine, so consumption of a capsule containing about 50-100 seeds can lead to severe anticholinergic toxicity [11].

Datura stramonium L. is a wild plant that grows in almost every region of our country on the roadsides and in empty areas. Plants are collected and dried and then leaves are prepared as cigatette for asthma and bronchitis. Seeds are used in acne, eczema, hemorrhoid treatment and antispasmodic. Ointment is also applied against regional pain [11]. The flowers of Datura stramonium L. especially the leaves, are used against asthma, cough and cramps [9].

Aerial parts of Datura metel L. include datura metelin C,D,E,G, leaves contain secowithametelin, daturiline, and vitamin $\mathrm{C}$, also roots have hyocine, hyoscyamine secondary metabolites [12].

Datura innoxia Mill. (Solanaceae) contains many alkaloids. Within 50 of excess alkaloids were detected [13].

\section{Results}

This review was carried out to investigate the antifungal effects of Datura species grown in Turkey. Many articles have been examined in our research and the results have been presented. The analyzed articles and the results are given in paragraphs. According to our research , Datura stramonium L., D. metel L. and D. innoxia Mill. have antifungal effects at different rates on different fungi.

Iranbakhsh et al. [14] reported that seed extract of Datura stramonium L. had inhibitory effect on Certocystis ulmi by 11 $\mathrm{mm}$, on Fusarium semitectum by $6 \mathrm{~mm}$ but it wasn't effective on Rhizoctonia solani; flower extract had inhibitory effect on
Certocystis ulmi by $20 \mathrm{~mm}$, on Rhizoctonia solani by $15 \mathrm{~mm}$ but it wasn't effective on Fusarium semitectum; in the generative stage, root extract had inhibitory effect on Certocystis ulmi by $10 \mathrm{~mm}$, on Fusarium semitectum by $6 \mathrm{~mm}$ but it wasn't effective on Rhizoctonia solani; in the vegetative stage, root extract had inhibitory effect on Certocystis ulmi by $16 \mathrm{~mm}$, but it wasn't effective on Rhizoctonia solani and Fusarium semitectum; in the generative stage, stem extract had inhibitory effect on Fusarium semitectum by $8 \mathrm{~mm}$, but it wasn't effective on Certocystis ulmi and Rhizoctonia solani; in the vegetative stage, stem extract had inhibitory effect on Certocystis ulmi by $10 \mathrm{~mm}$, on Rhizoctonia solani by $20 \mathrm{~mm}$ and on Fusarium semitectum by $6 \mathrm{~mm}$; in the generative stage, leaf extract had inhibitory effect on Fusarium semitectum by $10 \mathrm{~mm}$, on Certocystis ulmi by $11 \mathrm{~mm}$, but it wasn't effective on Rhizoctonia solani; in the vegatative stage, leaf extract had inhibitory effect on Fusarium semitectum by 5 $\mathrm{mm}$, on Certocystis ulmi by $8 \mathrm{~mm}$, but it wasn't effective on Rhizoctonia solani; also methanol extracts were effective on Certocystis ulmi by $12 \mathrm{~mm}$, on Fusarium semitectum by $10 \mathrm{~mm}$ and no effective on Rhizoctonia solani and all extracts have no inhibitory effect on Fusarium colmorum.

Türküsay and Onoğur [15] researched Ficus carica L. , Hedera helix L., Datura stramonium L. , Nicotiana tabacum L., Xanthium strumarium L., Avena sativa L. extracts antifungal effect against Alternaria alternata, A. solani, Botrytis cinerea and Dreschslera sorakiniana. $H$. helix L. leaf extracts inhibited spore germination at the highest level and $D$. stramonium L. followed it. However, H. helix L. has come to the forefront in preventing pathogens colonies growth, followed by Ficus carica L. and Avena sativa L. extracts.

Rodino et al. [16] reported that extract of jimsonweed (Datura stramonium L.), common cocklebur (Xanthium strumarium L.), rosemary (Rosmarinus officinalis L.) and wormwood (Artemisia absinthium L.) showed antifungal properties by inhibiting mycelial growth against Alternaria alternata; generally ethanol extracts exhibited a higher antifungal property than aqueous extracts. Among the aqueous extracts, Jimsonweed showed the best antifungal activity and flowers of jimsonweed has a better effect than leaves.

Sasode et al. [17] reported that $10 \%$ crude extract of the devil's apple inhibited the growth of the Alternaria brassicae fungus by $39.22 \%$ and it's $10 \%$ boiled extract had $19.92 \%$ inhibitory effect.

Rodino et al. [16] observed that $2.5 \%, 5 \%$ and $10 \%$ leaf ethanol extracts of devil's apple inhibited mycelium growth against Alternaria alternata and their inhibition percentages were $30 \%, 83.33 \%, 60 \%$, respectively. On the other hand, 
researchers reported that $2.5 \%, 5 \%$ and $10 \%$ fruit ethanol extract of devil's apple inhibition rates were $20 \%, 50 \%, 16.7$ $\%$, respectively. Whereas, Kumar et al. [18] determinated that $40 \%$ dozes of devil's apple ethanol extract inhibited mycelium growth $93.36 \%$. In addition, , Bagri et al. [19] reported that Datura sp. leaf preparations inhibited micelle growth and spore germination of Alternaria alternata and caused a high level of decrease in fruit decay density and also, Datura $s p$. leaf preparation was as effective as Kitazine fungus.

Khallil [20] reported that spore germination of Alternaria solani in the devil apple's aqueous extract was $\% 69.1 \pm 6.5$.

Kumar Meena et al. [21] reported that the extract of $25 \%$ of the leaves of Datura stramonium L. reduced the growth of Alternaria alternata fungus by $56.78 \%$ and the increased doses prevented the fungus growth, so much.

Kantwa et al. [22] reported that the Datura leaf extract inhibited mycelial growth of Alternaria alternata fungus by $40.33 \%$.

Anamika and Simon [23] determined that $10 \%$ aqueous extract of Datura stramonium L. inhibited the growth of Alternaria alternata fungus by $40.9 \%$ and spore germination by $32.5 \%$.

Hannan et al. [24] reported that Datura stramonium L. extract is highly effective against Alternaria alternata.

Satish et al. [25] found that the antifungal effect of $25 \%$ aqueous extract of Datura stramonium L. aganist to some Fusarium species was $87.25 \pm 0.85 \%$ for $F$. equiseti; $75.00 \pm 1.08$ for $F$. moniliforme; $68.25 \pm 1.11 \%$ for $F$. semitectum; $62.00 \pm 0.91 \%$ for $F$. graminearum; $67.50 \pm 1.19 \%$ for $F$. oxysporum; $77.00 \pm$ 1.29 for F. proliferatum; $70.00 \pm 0.91 \%$ for $F$. solani and $66.75 \pm$ $1.11 \%$ for F.lateritium.

Surender Kumar [26] reported that Datura stramonium L. extract inhibited mycelial growth of Fusarium moniliforme by $56 \%$.

Sharma et al. [27] investigated the antifungal effect of extracts obtained from Datura stramonium L. against Aspergillus flavus, Aspergillus niger, Fusarium culmorum and Rhizopus stolonifer. The most effective extract was a methanol extract, and the most effective part of the plant was leaf for Rhizopus stolonifer, while callus extract was for other fungi; The best antifungal effect was against Rhizopus stolonifer fungus, followed by Fusarium culmorum, Aspergillus flavus and Aspergillus niger respectively. Uma Reddy [28] reported that leaf extract of D. stramonium $L$. was effective against Aspergillus niger and Fusarium sp.

Singh et al. [29] determinated that extract of eucalyptus (Eucalyptus sp.), devil's apple (Datura stramonium L. ) and stabragh (kapok tree) (Calotropis procera (Aiton) W.T. Aiton) limited Fusarium oxysporum f.sp. chrysenthemi fungus growth.

Shivpuri et al. [30] reported that extracts of Datura stramonium. L., Azadirachta indica Juss., Polyalthia longifolia (Sonn.) Thwaites, Ocimumun sanctum Linn. showed antifungal properties against $F$. oxysporum fungus.

Arzoo ve Biswas [31] claimed that Datura stramonium L. aqueous extract inhibited mycelial growth of Fusarium oxysporum f.sp. lycopersici by $13 \%$.

In the study conducted by Salman and Faraj [32], the effect of Datura stramonium L. extract against Candida albicans was investigated. The minimum inhibitory concentration (MIC) was $3.12 \mathrm{mg} / \mathrm{ml}$. Datura stramonium L. leaf extract was tested for sensitivity to different concentrations and as a result zone of inhibition was determined as $12.00 \mathrm{~mm}$ at $200 \mathrm{mg} / \mathrm{ml}, 17.00$ $\mathrm{mm}$ at $150 \mathrm{mg} / \mathrm{ml}$ and $26.00 \mathrm{~mm}$ at $100 \mathrm{mg} / \mathrm{ml}$, respectively. Chohan et al. [33] reported that $8 \%$ aqueous extract of Datura stramonium L. leaves inhibited Fusarium oxysporum mycelial growth by $28.5 \%$.
Bhardwaj et al. [34] investigated the inhibitory effect of Datura stramonium L. methanol leaf extract on Colletotrichum lindemuthianum in vitro media. $40 \%$ inhibition at $250 \mathrm{ppm}$, $55.56 \%$ inhibition at $500 \mathrm{ppm}$ and $60 \%$ inhibition at $1000 \mathrm{ppm}$. In another study, it was reported that Datura metel L. leaf extract showed a strong antifungal effect against Macrophomina phaseolina and methanol extract gave better results than chloroform extract. The MIC value of methanol extract of Datura metel L. was determined to be $20 \mu \mathrm{g} /$ disc [35].

Mogita et al. [36] Allium sativum L., A. cepa L., Cleome gynandra L., Azadirachta indica Juss. , Datura stramonium L., Aloe vera (L.) Burnm., Lantana camara L. and Eucalyptus globulus Labill. In vitro antifungal activity against $C$. lindemuthianum was observed and the best antifungal activity was observed in Aloe vera leaf extract $(90.6 \%)$ and Datura stramonium L. extract (65.99\%) was second.

Sahu et al. [37] reported that Datura stramonium L. extract showed a $34.65 \%$ mycelial inhibition effect against Alternaria solani.

Shinde and Dhale [38] investigated the antifungal activity of Ocimum tenuiflorum L. and Datura stramonium L. extracts on Fusarium oxysporum and Rhizopus stolonifer fungi. According to this study, Datura stramonium L. stem bark alcoholic extract showed maximum antifungal activity. In the plants parts, the most antifungal effect on both fungus was at stem bark extract and then were at leaves and root bark respectively.

In a study conducted by Alemu et al. [39] , antifungal effects of 20 plants against Colletotrichum gloeosporioides were investigated. Datura stramonium L. methanol extract showed a very good antifungal effect against the tested fungus, Datura stramonium L. and Eucalyptus globulus Labill. of leaf extracts inhibited the pathogenic spore germination more than the other extracts ( $14.7 \%$ and $15.7 \%$, respectively).

As a result of research, it was stated that the seed extract of Datura stramonium L. contains atropine alkaloids, scopolamine and diterpenes and is effective against $F$. oxysporum [40].

Satish et al. [41] researched that effect of jimsonweed (Datura stramonium L.), acacia (Acacia nilotica (L.) Willd. ex. Delile), sapodilla tree (Achras zapota L.), Indian gooseberry (Emblica officinalis Gaertn.), eucalyptus (Eucalyptus globulus Labill.), henna (Lawsonia inermis L.), Spanish cherry (Mimusops elengi L.), yellow flame tree (Peltophorum pterocarpum (DC.) Backer ex. K.Heyne), Buddha tree (Polyalthia longifolia (Sonn.) Thwaites), Prosopis juliflora (Sw.) DC, pomegranate (Punica granatum L.) and Syzygium cumini (L.) Skeels against Aspergillus species A. candidus, A. columnaris, A. flavipes, $A$. flavus, A. fumigatus, A. niger, A. ochraceus ve A. tamarii. In general, the extracts of all plants are effective against the fungus species; but the effect of the eucalyptus on the A.chraceus and A. tamarii fungi was minimal; Achras zapota L. and Polyalthia longifoli (Sonn.) Thwaites extracts were less effective than the extracts of other plants. The effect ratios of Datura stramonium L. $25 \%$ aqueous extract against Aspergillus sp. were Aspergillus candidus (87.25 \pm 0.85$)$, A. niger (77.00 \pm 1.29$)$, A. flavus $(75.00$ $\pm 1.08)$, A. tamarii $70.00 \pm 0.91)$, A.ochraeus (68.25 \pm 1.11$), A$. fumigatus $(67.50 \pm 1.19)$, A. flavipes $(66.75 \pm 1.11)$ and $A$. columnaris $(62.00 \pm 0.91)$. In addition, the effects of different extracts of Datura stramonium L. against Aspergillus flavus were methanol extract $(83.09 \pm 1.26)$, ethanol $(67.17 \pm 0.86)$, chloroform (66.08 \pm 1.08$)$, benzene (40.45 \pm 1.31 ) and petroleum ether $(35.79 \pm 1: 07)$.

Hongxia et al. [42] indicated that the extract obtained from seeds of Datura stramonium L. was a strong inhibitory effect, 
completely inhibiting the growth of Gibberella zeae and inhibited the growth of Phytophthora capsici by $96.91 \%$.

Mohammed et al. [43] reported that alkaloids of Datura stramonium L. was high antifungal effect on Aspergillus flavus (zone of inhibition $9.00 \pm 0.73 \mathrm{~mm}$ ).

Abayhne et al. [44] reported that Datura stramonium L. aqueous extract had good antifungal effects against Phytophthora infestans.

In their research, Begum et al. [45] found that Datura metel L. leaf extract was antifungal effect against Alternaria alternata $42 \%$, Curvularia lunata $37 \%$, Fusarium equiseti $38 \%$, Macrophomina phaseolina $53 \%$, Botryodiplodia theobromae 71 $\%$ and Colletrotrichum corchori $54 \%$.

Ranaware et al. [46] found that Datura metel L. leaf aqueous extract had a $44.25 \%$ antifungal effect on Alternaria carthami.

In a study conducted, methanol, chloroform and aqueous extracts obtained from leaf, root and stem of Datura metel L. were effective against Candida albicans, Aspergillus niger. The methanolic extract of the plant shows the maximum inhibition at the concentration of $15 \mathrm{mg} / 0.1$ against both the fungi [12]. Datura metel L has Withanolide compound which is antifungal steroidal lactones [47]. Withanolide compounds show significant cytotoxic, antibacterial, antitumor, antiinflammatory, sedative, cytostatic, hepatoprotective and immunosuppressive activity [48]. Singh et al. [49] conducted a study of the withanolide compounds Withametelin inhibited spore germination against 23 fungi (except Curvularia maculans and Colletotrichum sp.) at concentrations of 125 to 1000 ppm. Alternaria alternata, A. brassicae, Cercospora abelmoschi, Curvularia sp., Heterosporium sp. and Ustilago cynodontis fungi were observed to inhibit germination at a concentration of $125 \mathrm{ppm}$ (lowest concentration).

It has been determined that the methanol extract of Datura metel L. has an inhibitory effect on Aspergillus fumigatus, $A$. flavus and $A$. niger and the disk diffusion method has a significant activity against Aspergillus with a concentration of $0.062 \mathrm{mg}$ methanol extract of D. metel L. [50].

A leaf extract of Datura metel L. protected Pennisetum glaucum against downy mildew disease caused by Sclerospora graminicola. On the other hand, Datura metel L. seed application by leaf extract was indicated to show $79 \%$ and $67 \%$ protection against downy mildew disease in greenhouse and field conditions respectively. It was also found that this extract is active in early and later stages of resistant plant growth. It has been observed that the highest value of the effect against Sclerospora graminicola was obtained by applying 2\% Datura metel L. for 3 hours [51].

Carvalho et al. [52] found that the aqueous extract of Datura metel L. plant did not prevent or even encourage the growth of Alternaria alternata.

Vikhe et al. [53] reported that $100 \%$ dozes Datura metel L. aqueous extract suppressed growth of Fusarium oxysporum, Alternaria alternata, Aspergillus niger, Aspergillus flavus, Phoma sps., Bipolaris sps., Helminthosporium, Rhizopus sps., Curvularia sps., Mucor sps. and Cladospernatum herbarum fungus.

Tiwari and Srivastava [54] stated that Datura alba (Syn. Datura metel L.) showed antifungal activity against Fusarium oxysporum, Alternaria porri, Aspergillus niger ve Sclerotium cepivorum.

Ali et al. [55] reported that leaf extract (10\%) of Datura fastuosa (Syn. Datura metel L.) showed 19.34\% inhibition against Fusarium oxysporum f.sp. pisi.
Mahmood et al. [56] investigated the antifungal effect of various doses (200 ppm, $400 \mathrm{ppm}$ and $600 \mathrm{ppm}$ )of aqueous extracts of Datura alba (Syn. Datura metel L.) against Fusarium solani. Researchers have determined that $200 \mathrm{ppm}$ and $400 \mathrm{ppm}$ doses are better than the $600 \mathrm{ppm}$ dose with a $83 \%$ inhibition rate.

Dabur et al. [57] reported that 2- ( 3, 4 - dimethyl - 2, 5 dihydro - 1H -pyrrol- 2-yl ) -1 - methylethyl pentanoate compounds which is isolated from Datura metel L were effective Candida albicans, Candida tropicalis, Aspergillus fumigatus, Aspergillus flavus ve Aspergillus niger.

The research conducted by Rajesh and Sharma [58] concluded that only chloroform extracts of $D$. metel L. effective against Aspergillus fumigatus, A.flavus ve A.niger and acetone, hexane, methanolic extracts of this plant no antifungal activity against fungus. However, The minimum inhibitory concentration (MIC) of chloroform fraction of D. metel L. was $625.0 \mu \mathrm{g} \mathrm{ml}{ }^{-1}$ against. A. fumigatus, A. flavus and A.niger, by microbroth dilution and percent spore germination inhibition assays. But the MIC by disc diffusion assay was observed to be $12.5 \mu \mathrm{g}$ disc $^{-1}$.

Kagale et al. [59] researched that effect of Datura metel L. extracts on mycelial growth and sclerotia production against Rhizoctonia solani. Colony diameter was determined as $14 \mathrm{~mm}$ in hot water, 12,6 in cold water, $7 \mathrm{~mm}$ in methanol, $21 \mathrm{~mm}$ in chloroform and $15 \mathrm{~mm}$ in petroleum ether.

In a study conducted by Khan and Nasreen [60] , inhibition of mycelial growth in 10\% methanol Datura metel L. leaf extract was found to be $68.65 \%$ in Colletotrichum capsici, $69.69 \%$ in Colletotrichum lindemuthianum, $50.00 \%$ in Fusarium moniliforme, , 63.33\% in Bipolaris oryzae, 64.70\% in Curvularia lunata, $75.55 \%$ in Rhizoctonia solani, $37.25 \%$ in Macrophomina phaseolina, $57.50 \%$ in Pyricularia oryzae and $57.77 \%$ in Fusarium oxysporum. In addition, inhibition of mycelial growth of $10 \%$ methanol in Datura stramonium L. leaf extract was $76.11 \%$ in Colletotrichum capsici, $42.42 \%$ in Colletotrichum lindemuthianum, $53.33 \%$ in Fusarium moniliforme, $72.85 \%$ in Alternaria alternata and $52.22 \%$ in Bipolaris oryzae, $75.29 \%$ in Curvularia lunata, $62.22 \%$ in Rhizoctonia solani, $64.70 \%$ in Macrophomina phaseolina, $65.00 \%$ in Pyricularia oryzae and 63.33\% in Fusarium oxysporum.

Shafique and Shafique [61] investigated the effect of Datura metel L. extract on Ascochyta rabiei in their research and found that $1.2 .3 .4 \% \mathrm{w} / \mathrm{v} \mathrm{n}$-hexane concentrations of shoot and root extracts of $D$. metel L. suppressed fungus growth. Percentage decrease in colony diameter of Ascochyta rabiei varied at shoot and root extracts. In the shoot extract, $34 \%$ in $1 \%$ n-hexane, $22 \%$ in $2 \%, 30 \%$ in $3 \%$ and $28 \%$ in $4 \%$ colony diameter decreased. Whereas, in the root extract, $34 \%$ in $1 \%$ n-hexane, $36 \%$ in $2 \%, 22 \%$ in $3 \%$ and $41 \%$ in $4 \%$ colony diameter decreased. In another study on the same fungus, the effect of Datura metel L. shoot and root on the fungus growth of aqueous and methanol extracts was investigated. Shoot and root extracts prepared with water showed significant antifungal effect compared to control but it was reported that shoot extract had better results than root extract. It was also concluded that the methanol extract was more effective than the aqueous extract in inhibiting the formation of fungi [62].

In another study, Datura metel L. leaf and flower extracts obtained with different solvents (petroleum ether, chloroform, methanol and aqueous) against different fungi (Trichoderma harzianum, Trichoderma viride, Fusarium oxysporum f. melonis, Fusarium oxysporum $f$. lycopersici and Fusarium oxysporum $f$. tuberosi.) were investigated. D. metel L. leaf and flower extracts showed antifungal activity against fungus at each concentration $(1 \%, 2 \%, 3 \%, 4 \%)$, Fusarium oxysporum $f$. sp. melonis more sensitive to the $D$. metel $\mathrm{L}$. leaf extract than the other two 
Fusarium species. It was also concluded that the antifungal effect of D.metel L. flower aqueous extract against T. viridis was higher (69\%) and both Trichoderma fungi was more sensitive to D.metel L. organic extracts than Fusarium species [63].

Jabeen et al. [64] researched that fruit extract with different solvent fractions of Datura metel L. had antifungal activity against Saclerotium rolfsii Sacc. and researchers found that the chloroform fraction had the best antifungal effect. It was also reported that the ethyl acetate fraction had less antifungal activity than the chloroform fraction and n-hexane, n-butanol, aqueous fractions did not show antifungal activity.

In the study conducted by Ravikumar and Garampalli [65] , it was determined that the antifungal activity ratio of Datura metel L. $4 \%$ aqueous extract was $21.30 \%$ and the antifungal activity rate of $2 \%$ aqueous extract was $6.66 \%$ against Alternaria solani.

Anwar et al. [66] determined that the aqueous extract of the devil's apple (Datura metel L.) decreased the growth of Alternaria alternata fungus by $9.41 \%$.

Javaid et al. [67] investigated that root, leaf and stem aqueous and hexane extracts of Datura alba Rumph. ex Nees had antifungal activity against Macrophomina phaseolina. At all concentrations $(1,2,3$ and $4 \%$ ), aqueous extracts showed the same effect as hexane extracts nearly; among aqueous extracts, with (\% 85-92) inhibitory effect the root extract showed the best antifungal property (inhibitory rate at leaf extract was \% 60-65, also at stem extract was \% 72-83); also among hexane extracts, the leaf extract showed more inhibitory effect with \% 72-84 than stem and root extracts (\% 59-79 and \% 57-62, respectively).

Javaid and Saddique [68] reported that methanolic leaf and fruit extracts of Datura metel L. were highly effective against Macrophomina phaseolina. It was also concluded that leaf extracts with all concentrations of chloroform, n-butanol and ethyl acetate fraction (3.125-200 $\mathrm{mg} \mathrm{mL}^{-1}$ ) and n-hexane fraction fruit extract prevented fungus growth.

Saha et al. [69] investigated the effect of aqueous and ethanol extracts of some plants on tea (Camellia sinensis L.) fungi. Aqueous and ethanol extracts of Datura metel L. highly effective on Colletotrichum camelliae, Curvularia eragrostridis and Botryodiplodia theobrome, while this plants aqueous and ethanol extracts was $100 \%$ effective on Colletotrichum camelliae.

At the research conducted by Ishnava et al. [70] is reported that extract $(50 \mathrm{~g} / 250 \mathrm{ml}$ ) of obtained from Datura metel L. leaves by use of solvents such as hexane, ethyl acetate, methanol and distilled water no antifungal effective against Aspergillus flavus, Aspergillus nidulans, Trichoderma harzianum, Trichoderma virans and Fuserium oxysporium, methanol extract of $D$. metel $\mathrm{L}$. showed minimum activity ( $3 \mathrm{~mm}$ ) against Aspergillus parasi, minimum inhibitory concentraction (MIC) was $60 \mathrm{ppm}$ and this plant played a more active role than Adhatoda vasic Nees., Aegle marmelos (L.) Correa, Annona squamosa L., Azadirachta indica Juss. , Citrus limon (L.) Osbeck, Cleome gynandraL. ,Holoptelea integrifolia (Roxb.)Planch, Jatropha curcas L., Moringa oleifera Lam., Murraya koenigii (L.) Spreng ,Nicotiana tabacum L. ,Ocimum sanctum Linn., Ricinus communis L., Trigonella foenumgraecum Linn. , Vitex negundo Linn., Zingiber officinale Roscoe against Alternaria sp. and D.metel L. showed antifungal activity against Aspergillus niger, Aspergillus awamori.

Sharma et al. [71] , it was found that aqueous extract of Datura metel L. against Sclerotinia sclerotiorum (17 mm inhibition length) was effective but Datura had no effect against Rhizoctonia solani and Fusarium oxysporum. The maximum antifungal activity of methanol extract was found to be active in leaves of Datura metel L. against Sclerotinia sclerotiorum with an inhibition length of $30 \mathrm{~mm}$ and inhibition length of $9 \mathrm{~mm}$ against Rhizoctonia solani as observed but no effect against Fusarium oxysporum.

In the study carried out by Malik [72] , fungicidal properties of different alcohol concentrations (10\%, 25\%, 50\%) against Aspergillus flavus of Alstonia scholaris (L.) R.Br., Argemone mexicana L. and Datura alba species were investigated and it has been observed that as the alcohol concentration increases, the inhibition rate of fungus radial growth increases.

Datura innoxia Mill. leaf, root, stem and seed extracts were obtained with methanol. These extracts were tested in Aspergillus niger, A.flavus, Alternaria solani, Helianthus sporium and Fusarium solani and it was determined that Datura inoxia Mill. Leaf, root, stem and seed methanol extracts were effective against to Fusarium solani but Aspergillus niger showed resistant to this plant extracts. It is reported that maximum inhibition percentage of leaves, stem, root and seed extracts were $79 \% 57.31 \%, 85.36 \%, 75.60$ against $F$. solani respectively [73].

Barman et al. [74], Datura innoxia Mill. were found to be effective against Alternaria alternata fungus.

Patil and Suryawanshi [75] reported that Datura innoxia Mill. leaf aqueous extract 's ( $100 \mathrm{mg} / 100 \mathrm{ml}$ ) inhibition fungus growth percentage was 46.67 against Alternaria alternata.

Pawar [76] investigated effect of 18 plant extracts against 5 pathogenic fungi (Alternaria alternata, Aspergillus niger, Curvularia lunata, Fusarium moniliforme and Trichoderma viride) and it is reported that Callistemon rigidus R.Br., Capsicum annuum L., Datura innoxia Mill., Dolichandrone falcata Wall. ex. DC., Lantana camara L. and Vitex negundo Linn. leaf extracts showed good antifungal activity against these fungi.

Abu Taleb et al. [77] reported that ethanol extracts ( 20\%) of Datura innoxia Mill. inhibited Fusarium solani growth and sporulation.

In a study by Guleria and Kumar [78] Murraya koenigii (L.) Spreng. , Datura innoxia Mill., Eucalyptus globulus Labill., Azadirachta indica Juss., Agave americana L. , Solanum xanthocarpum Schrad \& Wendl. and Adhatoda vasica Nees. didn't show inhibition effect against Alternaria alternata and Curvularia lunata at TLC plate.

Zaker [79] investigated the antifungal effects of methanolic and aqueous extracts of 6 different plants (Lavender, Datura, Artemisia, Thyme and Savory) at different concentrations $(5,10$, $15 \%$ ) against Fusarium solani. It was reported that Datura and Lavender methanol extracts were less effective at all three concentrations and Datura, Thyme, Savory, Lavender methanolic extracts (5\%) showed the lowest antimycelial effect.

Jalander et al. (2012) researched different concentrations (\%5, $\% 10, \% 15, \% 20$ ) of Datura stramonium L., D. innoxia Mill., $D$. metel L. ve D. ferox L. aqueous leaf extracts effects on mycelial growth against Alternaria solani (Ell.\& Mart.) Grout ve Fusarium oxysporum sp. udum Butler. and they have investigated that other concentrations except $5 \%$ showed antifungal activity. In addition, the best results have been obtained in $20 \%$ Datura stramonium L. leaf aqueous extract. However, $5 \%$ leaf aqueous extract increased pathogenic fungi growth compared to control.

\section{Conclusion}

In this rewiev, antifungal effects of $D$. stramonium L., $D$. innoxia Mill. and D. metel L. investigated. It was concluded that three Datura species exhibited antifungal activity at different rates against different fungi. In addition, the antifungal effect of this 
species varies depending on the plant part and type of solvent. The investigations show that there is a good potential to be used as a good fungicide in agricultural control thanks to the secondary metabolites it contains. The use of plants as antifungal agents may be an alternative to minimizing the residual problem.

\section{References}

[1] Davis, P.H. (ed.) . Flora of Turkey and The East Aegean Islands, Edinburgh Univ. Press, Edinburgh, 6., 451-452, 1965-1988.

[2] Vadlapudi, V.; Kaladhar , D.S.V.G.K. Antimicrobial study of plant extracts of Datura metel L. against some important disease causing pathogens, Asian Pacific Journal of Tropical Disease, 94-97, 2012.

[3] Singh, L.R. ; Singh, O.M. Datura stramonium: An overview of its phytochemistry and pharmacognosy. Research J. Pharmacognosy and Phytochemistry, 5.3., 143-148, 2013.

[4] Seçkin, T. İşlevsel bitki kimyası. Nobel Akademik Yayıncılık, Ankara, 680-681, 2014.

[5] Anonymous, 2017; https://www.google.com.tr

[6] Sakthi, S. ; Geetha, M.; Saranraj, P. Pharmacological screening of Datura metel and Acalypha indica for its antifungal activity aganist pathogenic fungi, International journal of pharmaceutical science and health care, 1.2., 1529, 2011.

[7] Berkov, S.; Pavlov, A.; Kovatcheva, P.; Stanimirova , P.; Philipov, S. Alkaloid Spectrum in Diploid and Tetraploid Hairy Root Cultures of Datura stramonium, Zeitscrift fur Naturforschung. C, Journal of Biosciences, 58. 1-2., 42. 2003 Jan-Feb .

[8] Philipov, S.; Berkov, S. GC-MS investigation of tropane alkaloids in Datura stramonium. Zeitscrift fur Naturforschung. C, Journal of Biosciences, 57.,5-6.,559561, 2002 May-Jun.

[9] Kulaksız, A., Kan, Y. Boru çiçeği (Datura stramonium L.)'nın botanik varyetelerinde farklı azot dozlarının tohum verimi ve alkaloit içerikleri üzerine etkileri, $S$. $\ddot{U}$. Ziraat Fakültesi Dergisi,; 16, 29, 4-11, 2002.

[10] Sayyed, A., Shah , M. Phytochemistry, pharmacological and traditional uses of Datura stramonium L. review, Journal of Pharmacognosy and Phytochemistry, 2.,5., 123-125, 2014.

[11] Zengin, S.; Yılmaz, D.; Al, B.; Boğan, M.; Yıldırım, C. Afrodizyak etki için Datura stramonium L. kullanımı ve antikolinerjik intoksikasyon: Üç vaka, Causapedia hakemli olgu dergisi, 2., 383, 2013.

[12] Shah, H.; Verma, S.; Tripathi, R. Anti-fungal screening and quantification of Datura metel Linn. Colombia Journal of Pharmaceutical Sciences, 1.,1-9., 2014.

[13] Berkov, S.; Zayed, R. Comparison of tropane alkaloid spectra between Datura innoxia grown in Egypt and Bulgaria, Zeitscrift fur Naturforschung. C, Journal of Biosciences, 59., 3-4.,184-186, 2004 Mar-Apr.

[14] Iranbakhsh, A.; Ebadi, M.; Bayat, M. The Inhibitory Effects of Plant Methanolic Extract of Datura stramonium L. and Leaf Explant Callus Against Bacteria and Fungi, Global Veterinaria, 4.,2., 149-155, 2010.

[15] Türküsay, H.; Onoğur, E. Bazı Bitki Ekstraktlarının In vitro Antifungal Etkileri Üzerine Araştırmalar, Turkish Journal of Agriculture and Foresty, 22., 267-271, 1998.

[16] Rodino, S.; Butu, M.; Petrache, P.; Butu, A.; Cornea, C.P. Antifungal Activity of Four Plants against Alternaria alternata, Scientific Bulletin. Series F. Biotechnologies, 18.,1.,60-65, 2014.

[17] Sasode, R.S.; Prakash, S.; Gupta, A.; Pandya, R.K.; Yadav, A. In Vitro Study of Some Plant Extracts Against Alternaria brassicae and Alternaria brassicicola, Journal of Phytology, 4.,1.,44-46, 2012.

[18] Kumar, A.; Gour, H.N.; Sharma, P.; Shah, R. Investigations on Variability and Eco-friendly Management of Alternaria alternata Causing Tomato Blight, VEGETOS, 5.,1., 5258.2012.

[19] Bagri, R.K.; Yadav, R.K.; Pankaj, S.; Choudhary S.C.L. Performance of Partially Purified Plant Product Preparations Against Fruit Rot of Chilli Caused by Alternaria alternata, Indian Journal of Plant Protection, 39.,2., 141-145, 2011.

[20] Khallil, A.M. Phytofungitoxic Properties in the Aqueus Extracts of Some Plants, Pakistan Journal of Biological Sciences, 4.,4., 392-394, 2001.

[21] Kumar Meena, R.; Sharma, S.S.; Upaydahyay, B. Integrated management of leaf blight of Isabgol caused by Alternaria alternata, Indian Phytopath, 67.,2.,179-183, 2014.

[22] Kantwa, S.L.; Tetarwal, J.P.; Shekhawat, K.S. In vitro effect of fungicides and phyto-extracts against Alternaria alternata causing leaf blight of groundnut, IOSR Journal of Agriculture and Veterinary Science (IOSR-JAVS),7.,6.,2831,2014.

[23] Anamika \& Simon, S. Inhibitory effect of botanical extracts against Alternaria alternata of aloe vera dry rot, Archives of Phytopathology and Plant Protection, 44.,15., 14621466, 2011.

[24] Hannan, A.Mukhtar, I.Riaz, T.Khan, S.N., Effect of plant extracts on black point infection of wheat, Mycopath,3., 1., 2., 53-55,2005.

[25] Satish, S.; Raghavendra, M.P.; Raveesha, K.A. Antifungal potentiality of some plant extracts against Fusarium sp., Archives Of Phytopathology And Plant Protection, 42.,7., 618-625,2009.

[26] Surender Kumar, B. Antifungal Potential of Plant Extract Against Fusarium moniliforme Sheldon, ORYZA-An International Journal on Rice, 48.,3., 278-279, 2011.

[27] Sharma, R.A.; Sharma, P.; Yadav, A. Antimicrobial Screening of Sequential Extracts of Datura stramonium L., International Journal of Pharmacy and Pharmaceutical Sciences, 5.,2., 401-404, 2013.

[28]Uma Reddy, B. Antimicrobial Activity of Datura stramonium L. and Tylophora indica (Burm.F.) Merr., Pharmacologyonline, 1.,1293-1300, 2009.

[29]Singh, P.K.; Kumar, V. Effectiveness of plant extract in controlling wilt pathogen of Chrysanthemum, Bioscience Discovery, 2.,2., 232-235, 2011.

[30]Shivpuri, A.; Sharma, O.P.; Jhamaria, S.L.Fungitoxic Properties of Plant Extracts Against Pathogenic Fungi, J. Of Mycology and Plant Pathology, 27.,1., 29-31, 1997.

[31]Arzoo, K.; Biswas, S.K. Evaluation of Antifungal activity Of Medicinal Plant Extracts against Fusarium oxysporum f.sp. lycopersici, AGRIWAYS, 1.,1.,54-55, 2013.

[32] Salman , A.Y.; Faraj, M.K. Effect of hydroalcoholic leaves extract of Datura stramonium on pathogenic Candida albicans , The Iraqi Journal of Veterinary Medicine, 39.,2.,55-61, 2015.

[33] Chohan, S.; Atiq, R.; Mehmood, M.A.; Naz, S.; Siddique, B.; Yasmin, G. Efficacy of few plant extracts against Fusarium oxysporum f. sp. gladioli, the cause of corm rot of gladiolus, 
Journal of Medicinal Plants Research., 5.,16., 3887-3890, 2011.

[34] Bhardwaj, J.; Seth, MK.; Gogoi , R. Evaluation of antifungal efficacy of plant extracts against seed-borne fungi Colletotrichum lindemuthianum, International Journal of Current Science, 18.,49-54,2015.

[35] Lakshmeesha, TR.; Sateesh, MK.; Vedashree, S.; Sofi, M. Antifungal activity of some medicinal plants on Soybean seed-borne Macrophomina phaseolina, Journal of Applied Pharmaceutical Science, 3.,2.,84-87, 2013.

[36] Mogita, W.G.; Ochuodho, J.O.; Gohole, S.L. Screening of plant extracts for antifungal potential against Colletotrichum lindemuthianum, First International Research and Innovation Conference, 141-150, 28-30 August 2013

[37] Sahu, D.K.; Khare, C.P; Patel, R. Eco friendly management of early blight of tomato using botanical plant extracts, Journal of Industrial Pollution Control, 30., 2., 215-218, 2014.

[38] Shinde, V.; Dhale, D.A. Antifungal properties of extracts of Ocimum tenuiflorum and Datura stramonium against some vegetable pathogenic fungi, Journal of Phytology, 2011; 3., 12.,41-44, 2011.

[39] Alemu, K.; Ayalew, A.; Weldetsadik, K. Evaluation of antifungal activity of botanicals for postharvest management of mango anthracnose (Colletotrichum gloeosporioides), International Journal of Life Sciences, 8., 1., 1-6, 2014.

[40] Anonymous, 2008. Assessment of Bioactivity of Some Locally Available Medicinal and Aromatic Plants in Management of Pests and Diseases of Medicinal Plants in West Bengal, Ramakrishna Mission. Medicinal Plants Institute, Ramakrishna Mission \& Department of Food Processing Industries, Government of West Bengal, Kolkata, West Bengal, India.

[41] Satish, S.; Mohana, D.C.; Ranhavendra, M.P.; Raveesha, K.A. Antifungal activity of some plant extracts against important seed borne pathogens of Aspergillus sp., Journal of Agricultural Technology, 3., 1., 109-119, 2007.

[42] Hongxia, Z.; Ruirui, F.; Linfeng, H. Preliminary Antifungal Research of Datura stramonium L. on Phytopathogens, Journal of Henan Institute of Science and Technology (Natural Sciences Edition), 2., 7., 2015.

[43] Mohammed, G.J.; Hameed, I.H.; Kamal, S.A. Study of secondary metabolites produced by Aspergillus flavus and evaluation of the antibacterial and antifungal activity, African Journal of Biotechnology, 2016.

[44] Abayhne, M.A.; Chauhan, N.M. Antifungal activity of various medicinal plants against late blight of potato from Ethiopia, Journal of Scientific Research \& Reports, 12.,5., 19, 2016.

[45] Begum, J.; Yusuf, M.; Chowdhury, U.C.; Khan, S.; Anwar, M.N. Antifungal activity of forty plants against phytopathogenic fungi, Bangladesh J. Microbiology, 24.,1., 76-78,2007.

[46] Ranaware, A.; Singh, V.; Nimbkar, N. In vitro antifungal study of the efficacy of some plant extracts for inhibition of Alternaria carthami fungus, Indian Journal of Natural Products and Resources, 1.,3.,384-386,2010.

[47] Choudhary, M.I.; Shahwar, D.; Parveen, Z.; Jabbar, A.; Ali, I.; Rahman, A. Antifungal steroidal lactones from Withania coagulance, Phytochemistry, 40.,4.,1243-1246, 1995.
[48] Maheshwari, N.O.; Khan, A.; Chopade, B.A. Rediscovering the medicinal properties of Datura sp.: A review, Journal of Medicinal Plants Research, 7.,39., 2885-2897, 2013.

[49] Singh, U.P.; Prakash, O.; Ray, A.B. Antifungal activity of Withametelin, a Withanolide isolated from Datura metel, Mycobiology, 29.,2., 96-99, 2001.

[50] Dabur, R.; Singh, H.; Chhillar, A.K.; Ali, M.; Sharma, G.L. Antifungal potential of Indian medicinal plants, Fitoterapia, 75.,389-391, 2004.

[51] Kumar, S.; Devaiah, P.; Mahadevappa, G.H.; Shetty, H.S. Induction of systemic resistance in pearl millet (Pennisetum glaucum) against downy mildew (Sclerospora graminicola) by Datura metel extract, Crop Protection, 28., 783-791, 2009.

[52] Carvalho, D.D.C.; Alves, E.; Camargos, R.B.; Oliveira, D.F.; Scolforo, J.R.S.; Carvalho, D.A.; Batista, T.R.S. Plant extracts to control Alternaria alternata in Murcott tangor fruits, Revista Iberoamericana , 28.,4.,173-178, 2011.

[53] Vikhe, A.M.; Wabale, H.S.; Wabale, A.S.; Reddy, P.G. Efficacy of Plant Extracts against the Seed Borne Fungi of Zea mays L., ASIAN J. EXP. BIOL. SCI. SPL, 109-111, 2010.

[54] Tiwari, B.K.; Srivastava, K.J. Studies on bio-efficacy of some plant extracts against pathogens of onion, News Let. Nat. Hort. Res. Dev. Found, 24.,1.,6-10, 2004.

[55] Ali, M.; Lal, M.; Khan, A.; Singh, V.; Singh, P. K. Evaluation of leaf extracts and essential oils against Fusarium oxysporum f.sp. pisi -the causal agent of pea wilt, Indian Phytopath, 66.,3.,316-318, 2013.

[56] Mahmood, R.; Naseer, M.; Shahid, A.A.; Usmani, A.; Ali, A. Screening of indigenous weed extracts against Fusarium solani with an emphasis to soil fertility-related microbial activities, Journal of Food, Agriculture \& Environment, 12.,2., 958-962, 2014.

[57] Dabur, R.; Chhillar, A.K.; Yadav, V.; Kamal, P.K.; Gupta, J.; Sharma, G.L. In vitro antifungal activity of 2-(3,4dimethyl-2,5-dihydro-1H-pyrrol-2-yl)-1-methylethyl pentanoate, a dihydropyrrole derivative, Journal of Medical Microbiology, 54.,549-552, 2005.

[58] Rajesh, Sharma, G.L. Studies on antimycotic properties of Datura metel, Journal of Ethnopharmacology, 80., 193197, 2002.

[59] Kagale, S.; Marimuthu, T.; Thayumanavan, B.; Nandakumar, R.; Samiyappan, R. Antimicrobial activity and induction of systemic resistance in rice by leaf extract of Datura metel against Rhizoctonia solani and Xanthomonas oryzae pv. oryzae, Physiological and Molecular Plant Pathology, 65.,91-100,2004.

[60] Khan, Z.S.; Nasreen, S. Phytochemical analysis , antifungal activity and mode of action of methanol extracts from plnats against pathogens, Journal of Agricultural Technology, 6.,4.,793-805,2010.

[61] Shafique, S.; Shafique, S. Antifungal activity of n-hexane extracts of Datura metel against Ascochyta rabiei, Mycopath, 6.,1\&2., 31-35,2008.

[62] Bajwa, R.; Shafique, S.; Shafique, S. Fungitoxicity of aqueous and organic solvents extracts of Datura metel against Ascochyta rabiei, Mycopath 6.,1\&2., 17-22,2008.

[63] Rinez, A.; Remadi, M.D.; Ladhari, A.; Omezzine, F.; Rinez, I.; Haouala, R. Antifungal activity of Datura metel L. organic and aqueous extracts on some pathogenic and antagonistic fungi, African Journal of Microbiology Research,7.,16., 1605-1612, 2013. 
[64] Jabeen, N.; Javaid, A.; Ahmed, E.; Sharif, A. Management of causal organism of collar of bell pepper ( Sclerotium rolfsii) by organic solvents extracts of Datura metel fruit, Pakistan Journal of Phytopathology, 26.,1.,15-20, 2014.

[65] Ravikumar, M.C.; Garampalli, R.H. Antifungal activity of plants extracts against Alternaria solani, the causal agent of early blight of tomato, Archives of Phytopathology and Plant Protection, 46.,16.,1897-1903,2013.

[66] Anwar, W.; Haider, M.A.; Aslam, M.; Shahbaz, M.; Khan, S.N.; Bibi, A. Assesment of antifungal potentials of some aqueous plant extracts and fungicides against Alternaria alternata, J.Agris. Res, 53.,1.,75-81, 2015.

[67] Javaid, A.; Amin, M.; Hasmi, S.S. Antifungal Activity of Datura alba against Macrophomina Phaseolina, Pak. J. Phytopathol, 20.,2.,175-179, 2008.

[68] Javaid, A.; Saddique, A. Control of charcoal rot fungus Macrophomina phaseolina by extracts of Datura metel L., Natural Product Research, 26.,18.,1715-1720, 2012.

[69] Saha, D.; Dasgupta, S.; Saha, A. Antifungal Activity of Some Plant Extracts Against Fungal Pathogens of Tea (Camellia sinensis), Pharmaceutical Biology,43.,91.,87-91, 2005.

[70] Ishnava, K.B.; Chauhan, K.H.; Bhatt, C.A. Screening of antifungal activity of various plant leaves extracts from Indian plants, Archieves of Phytopathology and Plant Protection, 45.,2.,152-160, 2012.

[71] Sharma, D.; Sharma, Y.; Nagar, A. Comparative study of different flowering plants on the basis of their antifungal activity, International Journal of Advanced Technology in Engineering and Science , 3.,1.,365- 373, 2015.

[72] Malik, V. Screening of medicinal plants extracts to control growth of opportunistic fungus (Aspergillus flavus), Asian Journal of Science and Technology, 6.,2., 1100-1102, 2015.

[73] Kalim, M.; Hussain, F.; Ali, H.; Ahmad, I.; Iqhal, M.N. Antifungal activities of methanolic extracts of Datura innoxia, PSM Biological Research,1.,2., 70-73, 2016.

[74] Barman, H.; Roy, A.; Kumar Das, S. Evaluation of Plant Products and Antagonistic Microbes Against Leaf Blight
(Alternaria alternata), A Devastating Pathogen of Tomato, Trends in Biosciences, 8.13., 3374-3377,2015.

[75] Patil, J.S.; Suryawanshi, N.S. Management of Alternaria alternata causing fruit rot of Strawberry using various plant extracts, Int. J. of Life Sciences, Special Issue, A5, 4246, 2015.

[76] Pawar, B.T. Antifungal activity of some leaf extracts against seed-borne pthogenic fungi, International Multidisciplinary Research Journal, 1.,4.,11-13, 2011.

[77] Abu Taleb, A.M.; El Deeb, K.; Al Otibi, F.O. Bioactivity of some plant extracts against Drechslera biseptata and Fusarium solani, Journal of Food, Agriculture \& Environment, 9.,3\&4., 769-774, 2011.

[78] Guleria, S.; Kumar, A. Antifungal activity of some Himalayan medicinal plants using direct bioautography, Journal of Cell and Molecular Biology, 5.,95-98, 2006.

[79] Zaker, M. Antifungal evaluation of some plant extracts in controlling Fusarium solani, the causal agent of potato dry rot in vitro and in vivo, International Journal of Agriculture and Biosciences, 3.4.,190-195, 2014.

[80] Jalander, V.; Gachande, B.D. Effect of aqueous leaf extracts of Datura sp. against two plant pathogenic fungi, International Journal of Food, Agriculture and Veterinary Sciences,2.,3.,131-134,2012 